

Review Article

\title{
Education and Entrepreneurship: Policy Review of South Asian Countries
}

\author{
Krishna Bahadur Rai ${ }^{1 *}$
}

${ }^{1}$ Kathmandu University, School of Education, Hattiban, Lalitpur, Nepal

\begin{abstract}
In south Asian countries, the education policy makers and educators have been highly focusing to the development of entrepreneurship through the educational interventions. The courses of entrepreneurship development have been endorsed to the schools and universities. However, the domestic enterprises have been declining gradually. The paper aims to present the issues on modern education system and its role in mainstreaming of domestic enterprises in these countries. For looking the connections between these two phenomena, I collected and reviewed the existing policies and practices regarding education system and entrepreneurship development. The study explored that the modern education system have not been supporting to the domestic enterprises in south Asia and the citizens are on the 'middle of the road' of their entrepreneurial practices. The recommendation is that the educational policies and practices should be reviewed and implemented effectively to promote the domestic enterprises; otherwise, those enterprising activities will be declined for forever. The findings of this study have the implications to ensure the educational policies for promoting these enterprises.
\end{abstract}

Keywords: Domestic enterprise; entrepreneurship; entrepreneurship development; education system.

\section{Introduction}

The countries have been launching the modern educational system for socio-economic prosperity of their citizens. The wave of modern education speeded globally including the south Asian countries with the major objective of capitalization of the knowledge and innovations. Obviously, education produces new knowledge and skills that support to create the entrepreneurial activities. Today's knowledge-based economy requires the educational institutions to provide knowledge and motivations of entrepreneurial intentions to students (Bakar et al., 2015). However, this can only happen when the quality of education is ensured. During the implementation of quality education, there is blame like; education systems do not foster more to inventive thinking, communication skills, problem solving or the other competencies. Anyway, the education system is expected to be more enterprising and highly supportive to the human creativity.

Another component taken for this paper is "entrepreneurship" which has been perceived to the domestic enterprising activities; the process of starting and continuing to expand new businesses at the local places based on the local resources, skills and needs. It is also a part of culture, attached to individuals or community from

\section{Cite this article as:}

K.B. Rai (2018) Int. J. Soc. Sc. Manage. Vol. 5, Issue-2: 60-68. DOI: 10.3126/ijssm.v5i2.19394

$1 *$ Corresponding author

Krishna Bahadur Rai,

Kathmandu University, School of Education, Hattiban, Lalitpur, Nepal

Email: kraimrg@gmail.com

Peer reviewed under authority of IJSSM

(C) 2018 International Journal of Social Sciences and Management

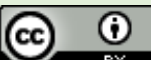

This is an open access article \& it is licensed under a Creative Commons Attribution 4.0 International License (https://creativecommons.org/licenses/by/4.0/) 
the very beginning, to generate the economic activities for their daily subsistence. The global economy has taken to entrepreneurship as a vital paradigm to force the citizens to be more productive and efficient for earning positive impacts to national economy and the quality of life of the citizens (Adejumo, 2000). The culture of entrepreneurship has shaped differently due to many reasons like geography, local resource availabilities, family and social orientations, territorial climate, human imaginations and other phenomena. In South Asian countries, there are myriad of domestic enterprises, which have been continued from generation to generation, and the inhabitants have been living with these enterprises.

I felt gap in the mutual connection between the modern education system launched in these countries and domestic enterprising practices. This paper examines the mutual connection between education system and entrepreneurship development in the context of south Asian countries i.e. Nepal, India, Pakistan, Bangladesh, Sri Lanka, Maldives, Bhutan and Afghanistan. The data on education and entrepreneurship development were collected from policy documents; previous research papers and other articles. The collected data were analyzed for assessing the realities on the linkage between the modern education and domestic enterprises.

\section{Education and Entrepreneurship}

A highly educated entrepreneur results in better capabilities and performances for the firms (Parker and Praag, 2006). Kirby (2005) argues that the traditional education system stultifies rather than develops the requisite attributes and skills to produce entrepreneurs and proposes that if entrepreneurs are to be developed, considerable changes are required in both the content and process of learning (p. 173). Currently, universities and other educational institutions are expected to play a new role in society in addition to research and teaching by applying a 'third mission' of economic development (Etzkowitz et al., 2000). It is widely accepted that the educated individuals can be the innovators and more entrepreneurial workforce and discover the potentialities of economic activities. But, the education system must shift the emphasis in learning from educating 'about' entrepreneurship to educating 'for' it (Kirby, 2005). The schools and universities have been intervening to the field of entrepreneurship development and various research works have been conducted in this area. The campaign of entrepreneurship education is taken as an essential stimulus for creating new businesses in the society.

When we go through the history of entrepreneurship education, Brockhaus (2001) has stated that the first course in entrepreneurship was offered at the Harvard Business School in 1947. Peter Drucker taught another early course at New York University in 1953. The academia started to concentrate to imply the constructive role of higher education to create the graduate entrepreneurs. Most of the countries have already added the subject of entrepreneurship with the education system from the very beginning and achieved socio-economic successes in the world.

The growing literature on entrepreneurship education tends to argue that a different learning environment is required to support the study of entrepreneurship within a university setting (Gibb, 2002) which takes to entrepreneurship as an approach or a subject. For taking as approach, the teaching technique is different that follows the action-oriented, encourages experiential learning, creativity, problem solving, project-based learning and peer evaluation. These processes provide the mix of enterprising skills and behaviors that are essential for creating and managing the enterprising activities (Jones and English, 2004). The education policies promotes entrepreneurs to be successful where innovative and creative skills acquired through the formal education imbued with instilling or imbibing of success traits in entrepreneur, create a culture of entrepreneurship in an economy (Taiwo and Tunde, 2016).

"Policy makers in Europe and United States believed that the increased levels of entrepreneurship can be reached through education and especially entrepreneurship education" (EC, 2006). Therefore, many of the European countries and the United States promoted, and implemented such education into school curricula (Kuratko, 2005). The effect of general and specific education and business trainings was positive and contributive to the promotion of enterprising activities (Oosterbeek, et al., 2010). FAO (2010) have conducted a case study on the programme named "Promoting employment and entrepreneurship for vulnerable youths in West Bank and Gaza Strip". One of the components of this study was "Junior Farmer Field and Life School (JFFLS)". The component was found highly effective on changing attitudes of the participants towards the entrepreneurial aspects and also found encouraging community interest and participation. This was a best evidence of knowledge and skill improvements in entrepreneurial works. From the layers of research works, it is concluded the education as a key trigger to evoke entrepreneurial inclinations (NKC, 2008).

The advancements of some countries are the results of entrepreneurship movements linking with the educational policies and practices. Taiwo and Tunde (2016) have attributed the success of entrepreneurship to the Chinese, Japanese and newly emerging economies to the cultures and the educational system of those countries. The African countries have the challenges to develop the skills and knowledge of their citizens and deploy them towards economic development (Taiwo and Tunde, 2016). How the education system is incorporating the aspects of entrepreneurship that is one of the main concerns for 
making citizens productive and innovative. In this respect, the nature and role of education should be supportive for catalyzing entrepreneurship, especially in the highly skilled and knowledge-driven sectors (NKC, 2008).

\section{Education Policies and Programmes}

The goal of education system and entrepreneurship development is same to make better prosperity of the citizens. Those agendas have mutual correspondence for their improved conditions if the practices have been shaped and launched in the same lines. The modern education system has been attempting to foster the employment, entrepreneurship and other social skills. But, the entrepreneurship has not been improving as expected in south Asian countries and most of the domestic enterprises have been declining from their field due to the multiple obstacles. The educational interventions are obviously based on the national policies; thus, I reviewed the educational policies of these countries for looking the priorities towards the entrepreneurship development and collected the realities on this issue.

In Nepal, the concept of modern education started in 1954 establishing Nepal National Education Planning Commission (NNEPC) and laid the foundation for a national education system within the framework of national unity, democracy, and development (MoE, 2010). The education policy focused to nurture the personality and inherent talents of the citizens with enhancing the national and social unity. The policy has given emphasis to produce the productive and skilled human resources for local and international job markets. The culture of periodic plan started from 1956 with the priorities of economic advancement; from the first five year plan, the government gave the priority to entrepreneurship education and skills development programmes. To produce the skilled human resources and foster enterprising activities, technical schools were established in Doti, Banke, Dang and Mustang districts as per the targets of establishing such four schools in different parts of Nepal. Likewise, ninth plan provisioned for enabling the human resources to make them entrepreneurial, self-employed through human resource development and extensive expansion of entrepreneurial and skill-oriented training programmes (GoN, 1996). Technical Education and Vocational Training Development Policy 2007 has given the emphasis to produce the technical human resources and providing vocational skills that directly helps to encourage towards the enterprising activities. Interim plan (2010 - 2013) has sated the objective of education system attached to livelihood, employment, skill-based and productive (GoN, 2010). It means the Government of Nepal has given wider space to entrepreneurship and livelihoods through the education system. In the Interim Plan, the policy has given emphasis to equitable access of education and literacy to all ethnicities of the population such as Dalit, Janajati and socio-economically deprived groups of Nepal so that they will be able to learn the knowledge and skills for their better livelihoods. It has also given priority to technical education and vocational skills (TEVT) as a special sector for enhancing the technical and vocational skills which promotes the entrepreneurship, self-employment and sustainable livelihoods. Hence, the GoN has envisioned to the national education system to make more connected to skills, enterprises and better livelihoods.

India has a pioneering status among developing countries for its early start on a variety of entrepreneurship education programs (Rehman, 2006). The Industrial Policy Resolution, 1956 gave high priority to the promotion of entrepreneurship. From the decade of 80 , the government of India started entrepreneurship education into technology and management institutions (Nalla and Sanapala, 2015). The Indian educational policy includes majorly a national curricular framework containing a common core along with flexible components. The part of 'common core' covers to the core areas of understandings like basic national identities, democracy, secularism, equality of sex, environment protection, small family norms etc. The next 'flexible component' initiates and promotes to the scientific approaches, appropriate skills and competencies, creative potentials and the entrepreneurship are included and promoted. The National Education Policy (2016) envisions a credible and high-performing education system to ensure inclusive quality education and lifelong learning opportunities for all and producing students/graduates equipped with the knowledge, skills, attitudes and values required to lead a productive life. It also participated in the country's development process; respond to the requirements of the fast-changing, ever-globalizing, knowledge-based economy and society (MoHRDI, 2016).

In India, National Policy for Skill Development and Entrepreneurship 2015 has been launched with detailed strategies of entrepreneurship development. It has been implementing various schemes like world class entrepreneurship education from the early stage, entrepreneurship courses 325 industrial clusters through 50 nodal entrepreneurship hubs; contact mechanism to peers, mentors and incubators; entrepreneurship hubs; catalyze a culture shift to encourage entrepreneurship, special focus to the scheduled communities and groups, women and fostering the social entrepreneurship and grassroots innovations. However, the major challenge that India is facing to provide sustainable livelihood opportunities and improve the quality of life of a large number of youth, using culturally acceptable modern technology and local solutions (Mehrotra, 2015). Educational framework for inculcating the entrepreneurial spirits seems far from being satisfactory (Dutta, 2012). 
The education system of Pakistan runs through the National Education Policy 2009 which comes in a series of education policies dating back to the very inception of the country in 1947 (GoP, 2009). The policy (1998 - 2010) was under implementation before this latest policy and it was not able to obtain the expected results like access, quality of educational opportunities. On the other hand, that policy could not cover the international campaigns like MDGs, EFA and challenges created by the globalization. Hence, the policy was launched for updating and obtaining results on these issues. One of the objectives was to enable an individual to earn honestly his/her livelihood through skills that contribute to the national economy and enables them to make informed choices in life (GoP, 2009). It has also taken the policy action to promote the universities and research institutes for giving the greater emphasis on mobilizing research for promoting the innovation in the economy. The policy has provisioned for strengthening the skills and innovations. It initiated the concept of university-industry partnership with R\&D. Government of Pakistan has launched the National Youth Policy 2008 with one of the principles of youth skills and entrepreneurship initiation. This policy initiated small incubator offices in the universities with equipped by all office facilities for young graduates so that the graduates may police up their ideas and implement to the venture activities. It has proposed the wider opportunities of trainings on counseling supports to potential and existing young entrepreneurs (GoP, 2008).

In Bangladesh, National Education Policy 2010 have been implementing with the aspect of emphasizing religion, science and technology. The policy has taken one of the major objectives to enable students to acquire skills in vocational education to facilitate self-employment, irrespective of levels of education (GoB, 2010). It has provisioned the vocational and technical education for producing skilled workforce and entrepreneurship; starts from the higher secondary level and managed the courses of business studies for promoting enterprises and industries. Now, the seventh Five Year Plan (2016 - 2020) is running with the slogan of 'Accelerating growth, empowering citizens' for overall development of Bangladesh. It has given the high priority to education sector for human capital formation process and empowered them to seek the curriculum relevant to labor market needs, self-employment generation, and export of skilled manpower (GoB, 2016).

In Afghanistan, the education system was highly disturbed due to the internal and external wars of 23 years. During the Taliban regime, the girls were banned to go to school. After 2002, the Ministry of Education launched the education policy with inclusive aspects and much democratic agendas. The policy was in favor of providing compulsory primary education without the discrimination of gender, ethnicity, language and religion. The policy started to explore the equitable opportunities for all of the rural provinces with unified curriculum. The policy was aligned to the quality education as per the needs of the society and focused to the vocational and professional education and trainings. The policy adopted the UN norms of humanitarian education, exchange of expertise with international communities and peaceful values.

The Ministry of Education's vision is to develop human capital based on Islamic principles, national and international commitments and respect for human rights by providing equitable access to quality education for all to enable them to actively participate in sustainable development, economic growth, stability and security of Afghanistan (GoA, 2010). The National Strategic Education Plan (2010 - 2014) has been developed in the light of the results achieved and lessons learned from the implementation of NESP (2006 - 2010). That policy had continued the provision of technical and vocational education and training (TVET) for promoting the entrepreneurship and employment but not stated directly with high priority. The government has launched the National Youth Policy 2013 and given priority to TVET but not recognized to the entrepreneurship development.

In Sri Lanka, the education system has achieved the remarkable progress in terms of basic education indicators as the result of the priority given to the human capital development, the Universal Free Education policy was introduced in 1945 (Liyanage, 2014). The government has launched different policies to the education sector but not focused directly to the entrepreneurship development. The Education Sector Development Framework and Programme 2006 was launched to bring about the considerable changes is education system in major four themes, i.e. 1) promoting equity by enabling all children in the country to access and complete basic and secondary education; 2) improve the quality of basic and secondary education; 3) enhancing economic efficiency \& equity of resource allocation and 4) strengthening education governance and service delivery (MoESL, 2006). This framework had not the provisions of entrepreneurship education and development. The national development plan focuses on entrepreneurship and skill development, improvement of technology and modernization of facilities, and others (Priyanath and Premaratne, 2014).

Royal Government of Bhutan has launched the National Education Policy 2011 with the vision of “....an educated and enlightened society of 'gyalyong gakid pelzom' at peace with itself, at peace with the world, built and sustained by the idealism and the creative enterprise of our citizens" (MoEB, 2012). It has launched National Employment Policy 2013 for achieving the Gross National Happiness (GNH) through gainful employment to the people. Bhutan has given the priority to the creative entrepreneurship for the sustainable livelihoods of the 
citizens. One of the missions was to build a broadly liberal, culturally sensitive, forward-looking, standards-based education system that combines the best of received wisdom of successive generations and the results of innovation and enterprise in the diverse fields of human endeavor (MoEB, 2012). Likewise, Bhutan Vision 2020 has also given the priority to entrepreneurship development particularly to micro, small and medium scale. Now, Eleventh Five Year Plan (2013 - 2018) is under implementation and with the provision of strengthening and promoting innovation, creativity and enterprise in education and the launching responsibility is given to Royal Education Council. It provisioned about the development of cottage and small industries (RGoB, 2013). The Royal Government of Bhutan (RGoB) focused on the development of human resources and the creation of a knowledge-based society through its National HRD Policy 2010; the Tertiary Education Policy of the Kingdom of Bhutan 2010 and the National Youth Policy 2011 (Khandu, 2014). In addition, other national policies have prioritized to the skills and knowledge as the driving forces of economic and social development.

In Maldives, the main goals of education system are to develop capable citizens with occupational knowledge and attitudes with a sense of dignity of labor and for preserving the environmental resources; ensuring universal primary education; developing the spirit of independence and selfreliance to enable them for improving the quality of their lives; strengthen the national consciousness and to preserve the cultural heritage; and to provide lifelong educational opportunities. Maldives has seen significant improvements in access to education over two decades; however, there are still many challenges impeding quality education in the Maldives. Maldives has three streams of education by nature i.e. informal training, which children receive from the family and island communities; Islamic religious instruction through private tutoring; and western model schooling started in 1960 with the instruction Englishmedium schools (UNESCO, 2007). The National Curriculum Framework of Maldives has taken the entrepreneurship as an approach of teaching and learning. The entrepreneurship is taught from the primary education in relation to the context of each learning areas.

\section{Analysis of the Realities}

There are varieties of domestic enterprising activities in south Asian countries with great potentialities. Most of the enterprising activities fall under the domestic types and category of cottage, micro, small and medium scale which have been supporting much not only from economic perspective, but also socially and politically because of their contributions to household employment, improvement of income distribution, poverty reduction and rural development. More than 90 percent of all private enterprises are under the category of SME in south Asia and employ round 62 percent of domestic workforce (ADB, 2014). But, the domestic enterprises are disadvantaged due to the lack of fundamental business factors like entrepreneurial orientations, managerial skills, trained labors, brands and networking (UN-ESCAP, 2011).

In the sector of education, the south Asian countries have been attempting to the agendas of compulsory basic education, education for all, technical skills and entrepreneurship education for upgrading the knowledgebased economies which make possible to invest human capital as the prerequisites of entrepreneurship development. South Asian governments have been adopting rights-based approaches to provide universal education but need to pay attention to the quality of education and training (UN-ESCAP, 2015). They have been implementing the policies and plans of education system to prepare productive citizens. Primary, secondary, vocational schools, universities, literacy programs, educational television, as well as various types of in-formal education have been expanding at an unprecedented rate. These countries have been investing the higher portion of their national budget. Nepal had allocated 13 percent of total budget in FY 2015/16 to education development (GoN, 2015). Likewise, India spent 14 percent of total national budget in 2014, Bangladesh 11.6 percent and Bhutan has spent 18 percent in the sector of formal education. Likewise, Afghanistan spent 12.8 percent, Pakistan 11.3 percent and Maldives 15.3 percent of their national budgets. These significant allocations indicate the high emphasis given to the formal, informal and non-formal education system in these countries. The campaign of 'education for all' to the south Asian countries has taken as a foundation of strategic development. Despite the high efforts on educational sectors, they have been experiencing the situation of poverty and unemployment. In Bhutan, the central government authority/institution is not directly responsible for entrepreneurship training nationally, unlike in the case of vocational trainings (MoYASL, 2007). Employment growth averaged only 1.8 percent annually in India and 2.6 percent annually in the rest of South Asia between 1992 and 2012, much lower than the GDP growth over the same period (UN-ESCAP, 2015). The south Asian countries have not achieved the expected growth rates and they are facing the stagnation of economic sectors, underemployment, rising unemployment levels and social exclusion for large sections of society.

South Asian countries have been endorsing the entrepreneurship courses in schools and universities. For example, Nepal has been providing the entrepreneurship education formally by the universities in BBA/S and $\mathrm{MBA} / \mathrm{S}$ courses and CTEVT have been launching the programmes of skill trainings and entrepreneurship development. In India, academic institutions like NISIET, the National Institute of Entrepreneurship and Small 
Business Development (NIESBUD), the Indian Institute of Entrepreneurship (IE), and the Entrepreneurship Development Institute of India (EDII), in addition to regional institutions, have utilized these grants for accelerating entrepreneurship activities (APO, 2007). Bangladesh has also implemented the entrepreneurship as the courses in the formal education system. Bangladesh Institute of Management (BIM) under the Ministry of Industry has been offering the course of entrepreneurship development. Other public and private universities have also launched the courses of innovation and entrepreneurship. In Pakistan, entrepreneurship has been taken as one of the major sector of employment opportunities, means of poverty reduction and national economic development. The youth entrepreneurship is being promoted by educational institutions like Lahore University of Management Sciences (LUMS), the Institute of Business Administration (IBA), and the Shell Tameer program. A number of business and management schools facilitate internships to enable students to gain practical experience in business management (APO, 2007).

In Afghanistan, at level of senior secondary, students can choose vocationally oriented subjects like agriculture, education, arts, culture and economics. After successfully completing lower secondary education pupils can get admission to technical and secondary vocational education. Students can choose a shortened technical programme with a nominal duration of 3 years or a longer programme with a nominal duration of 5 years. Afghanistan currently has 19 public and more than 75 private higher education institutions. The tremendous growth seen in private higher education institutions, the MoHE is currently pursuing a policy halting the establishment of private universities. More than 97 vocational schools and 62 institutes of medical science and technical and vocational are majorly providing the entrepreneurship education and skill trainings. The National Institute for Management and Administration was established in 2008 in Kabul and has been providing entrepreneurship education for 2,500 students from around the country (GoA, 2011). In Sri Lanka, there are 15 universities, seven post-graduate institutions, 10 other higher education institutions and 1138 technical and vocational education and training institutes which are all public institutions (Liyanage, 2014). University of Vocational Technology (UNIVOTEC) provides degree level programs for those who come through the NVQ Framework or who work in industry (GoSL, 2016). Bhutan has managed the livelihood skill courses also known as 'Occupational Skills Development Courses' shall be offered to classes IX to XII as optional subjects. While these courses shall focus on learning conceptual aspects with a high degree of creativity and innovation, the major focus shall be on development of 'skills', and 'values and attitudes' towards the world of work. The idea of entrepreneurship through cooperatives shall not only employ the majority of student graduates from Class X and XII in their communities, but contribute greatly towards ensuring food security in the country and the economic selfreliance of the GNH society (MoEB, 2012).

The governments of south Asia have promoted the education to foster the enterprising activities. Being these promotional interventions, the initiation and development of enterprises is not at expected level and majority of the citizens are living under poverty and unemployment. Offering such programs only at the college level may not be the best alternative. These countries have launched entrepreneurial education formally after the secondary level of school education. Secondary schools are generally seen by rural youth as a means of escape from rural areas and farming in most developing countries. One of the reasons for this situation is the lack of relevance of much of the general secondary curriculum to the needs of rural communities (Quiroz, 2002). Most of the domestic enterprises of rural villages have been declining rapidly due to the lack of relevant education. The people of those countries have been rapidly shifting from their indigenous knowledge system to the new ground of globalization. The modern education system fostered in south Asian countries highly promoting to the knowledge system tended to the globalization which has been tragically and forcefully destroying the cultures around the world (Reynar, 2002). The classroom education system ignored to the entrepreneurial practices of the rural villages in south Asia.

On the other hand, the citizens who have been engaging to the enterprising activities are merely supported by the education system in south Asia. The micro and small enterprises (MSEs) in the rural villages of these countries have been dilapidated due to the various causes. The domestic entrepreneurs are still under the serious hindrances i.e. lack of entrepreneurial mindsets, weak inhouse training, lack of in-house capabilities for formalized learning, limited knowledge about external training opportunities and absence of local peer groups (Ahmed, Wahab and Mahood, 2011). Very little is still known about effective teaching techniques for entrepreneurship educators (Brockhaus, 2001), research and knowledge about how to teach entrepreneurship remains relatively underdeveloped, despite the growing demand for more entrepreneurial-oriented graduates (Kirby, 2002). The report of GUESS (2011) has ranked Pakistan at lowest on student's intention to become an entrepreneur by starting their own business after completing the study (Hussain and Norashidah, 2015). This is especially valid in the rural where manual labor and trainings are widely considered of much lesser prestige than learning at the hands of books (Vollmann, 2010). In Nepal, most of the educated individuals are leaving their local opportunities of selfemployment and potential enterprising activities. The value 
of salaried jobs is higher within these countries because of the sophisticated life style show and the foreign employments are appreciated better due to the higher currency power of employer-countries.

The socio-economically deprived communities have been attempting to imitate the ways of other personalities of formally educated, and leaving their family skills and enterprises. In practice, the access of modern education system has been promoting more to the orientation of formal jobs and not motivating to the continuation of the cultural enterprises. On the other hand, more of the people of lower educated in rural villages have been governing specific jobs and skills, which are to be exercised by a special group of people, caste or family taken as granted (Vollmann, 2010). The communities of skilled works categorized under un-touchable groups or lower castes; therefore, most of them have left their family businesses for coming out of that negative discriminatory social response.

In south Asian countries, the enterprising practices are in the transition with the huge pile of confusions because of the conflict between the modern education system and traditional cultural practices mostly in the rural villages. The cultural enterprises are programmatically neglected by the education system launched and promoted to modern technologies and skills. The structural transformation in South Asia has moved from agriculture to services bypassing industry not allowing the substantial backward and forward linkages of industry to be harnessed for jobcreation (UN-ESCAP, 2015). The linkage of education system with cultural innovations and enterprises seem very weak so that the existing entrepreneurs could not get the opportunities of interacting between their family enterprises and modern technologies. On the other side, more than 80 percent of the workforce in South Asia is trapped in lowquality informal sector jobs with little or no social protection (Nayar et. al, 2012). The education system has not intervening constructively to promote these enterprises; hence, the entrepreneurship status of these people has been lagging behind in the liberal market economy.

The modern education system launched in the south Asian countries has not been supporting to the enterprises culturally established from the historical time. The vocational programs, in many developing countries, tend to be academic rather than really vocational in approach (Quiroz, 2002) and the orientation has been giving in same lines. Hence, the people of these countries are in the crossroad of changing their enterprising orientation as to the aspects of globalization explored by the modern education system and its movements. The situation of poverty and unemployment is remaining the same and huge amount of human resources has been temporarily migrating to the western and the countries of higher currency power. The south Asian countries failed to achieve the double digit increment in GDP due to the limited enterprising activities and other employment opportunities. The localization of educational courses have been ignoring much in practice and merely searching the importance and constructive knowledge system from the local practices of enterprises and livelihoods.

\section{Conclusion}

Obviously, the education system influences the knowledge base, the competence and preparing the attitudes of the individuals. The purpose of this paper was to explore the linkage between the education system and entrepreneurship development in the south Asian countries. South Asian countries have been attempting to promote education towards the entrepreneurship development for the purpose of better wellbeing of the citizens. The policy makers are aware of promoting the entrepreneurship education to their countries. The education and other policies have given emphasis to the entrepreneurship development in these countries. The educational institutions have been contributing much to generate the enterprising activities but they have not been found attached to the domestic enterprising practices and taken as an approach to entrepreneurship in pedagogical process. The classroom teaching/learning process made isolated to the students and the lack of action-based teaching hampered to the orientation to enterprising activities. The modern education system is directed by the globalization and western modality hence the connection with local, indigenous or cultural entrepreneurs weaker than the expected in practice. The investment in education could not contribute really to the development of entrepreneurial mind-sets and promotion of the enterprises attaching to the local opportunities. As the result, the entrepreneurship development lagged behind and the contribution of this sector remained at very small proportion in GDP.

The gaps on policy and practices are there in the linkage between the modern education and local knowledge system. Therefore, the entrepreneurship process was found in the "cross-road" situation due to the weak connection between education system and entrepreneurship approach. For maintaining the sustainable enterprising activities in rural and urban locations, there was found the need of transforming the education system towards the local practices of enterprising activities.

\section{References}

Ahmed V, Wahab MA and Mahmood H (2011) Effectiveness of HRD for developing SMEs in south Asia. SAARC Human Resource Development Centre, 1 - 92.

Asian Development Bank [ADB] (2014) Asian SME finance monitor 2014. Mandaluyong City: Author.

Asian Productivity Organization [APO] (2007) Entrepreneurship development for competitive small and medium enterprises. Tokyo: Author. 
Bakar R, Islam MA and Lee J (2015) Entrepreneurship education: Experiences in selected countries. International Education Studies 8(1): 88- 99.

Brockhaus RH (2001) Foreword. In: Brockhaus RH, Hills GE, Klandt $\mathrm{H}$ and Welsch HP (Eds), Entrepreneurship Education: A global view. Aldershot: Ashgate Publishing Ltd.

Dutta S (2012) Entrepreneurship and Global Competitiveness: A Study on India. Indian Journal of Industrial Relations 47(4): 617 - 633.

European Commission [EC] (2006) Entrepreneurship education in Europe: fostering entrepreneurial mindsets through education and learning. Final Proceedings of the Conference on Entrepreneurship Education in Oslo.

Etzkowitz H, Webster A, Gebhardt C and Terra B (2000) The future of the university and the university of the future: Evolution of ivory tower to entrepreneurial paradigm. Research Policy 29(2): 313-330.

Food and Agriculture Organization [FAO] (2010) Promoting employment and entrepreneurship for vulnerable youths in West Bank and Gaza Strip. Rome: Author.

Gibb A (2002) In pursuit of a new 'enterprise' and 'entrepreneurship' paradigm for learning: creative destruction, new values, new ways of doing things and new combinations of knowledge. International Journal of Management Reviews, 4 (3): 233 - 269.

Government of Afghanistan [GoA] (2010) National Strategic Education Plan 2010 - 2014. Kabul: Author.

Government of Afghanistan [GoA] (2011) National Education Interim Plan 2011 - 2013. Kabul: Author.

Government of Bangladesh [GoB] (2010) National Education policy 2010. Dhaka: Author.

Government of Bangladesh [GoB] (2016) Seventh Five Year Plan (2016 - 2020). Dhaka: Author.

Government of Nepal [GoN] (1996) Nepalko Nawaun Panchabarshiya Yojana, 1996/097 - 2001/02 [The Ninth Five Year Plan, 1996/097 - 2001/02]. Kathmandu: Author.

Government of Nepal [GoN] (2010) Nepalko Tribarshiya Yojana, 2010/11 - 2012/13 [The Three Year Intirim Plan, 2010/11 -2012/13]. Kathmandu: Author.

Government of Nepal [GoN] (2015) Nepalko sambidhan 2072 [The constitution of Nepal, 2015]. Kathmandu: Author.

Government of Pakistan [GoP] (2008) National youth policy 2008. Islamabad: Author.

Government of Pakistan [GoP] (2009) National education policy 2009. Islamabad: Author.

Government of Sri Lanka [GoSL] (2016) Programme Design: Skills for inclusive economic growth. Colombo: Author.

Hussain A and Noradhidah (2015) Impact of entrepreneurial education on entrepreneurial intentions of Pakistani students. Journal of Entrepreneurship and Business Innovation 2(1): 43 - 53. DOI: 10.5296/ jebi.v2i1.7534.

Jones C and English J (2004) A contemporary approach to entrepreneurship education. Education + Training, 46(8/9): $416-423$.

Khandu Y (2014) Technical and Vocational Education and Training (TVET): Training providers', employers', instructors' and trainees' attitudes to generic/ employability skills in Bhutan. Thimpu: MoLHR, Bhutan.

Kirby DA (2002) Entrepreneurship Education: can Business Schools meet the Challange? Paper presented at the ICSB World Conference, San Juan, Puerto Rico.

Kirby DA (2005) Entrepreneurship education: Can business schools meet the challenges? In Li ZG, Chen R \& Cannice M (Eds.), Cilicon Valley Review of Global Entrepreneurship Research (pp. 173 - 193). San Francisco: University of San Francisco.

Liyanage KIM (2014) Education system of Sri Lanka: Strengths and weaknesses. Retrieved from http://www.ide. go.jp/Japanese/Publish/

Download/ Report/2013/pdf/C02_ch7.pdf.

Mehrotra VS (2015) Integrating Academic and Vocational Education: Making the link through National Vocational Education Qualifications Framework. COMOSA Journal of Open Schooling 3(1): 30-48.

Ministry of Education [MoE] (2010) Ministry of Education: A glimpse. Kathmandu: Author.

Ministry of Education, Bhutan [MoEB] (2012) National education policy 2011. Thumpu: Author.

Ministry of Education, Sri Lanka [MoESL] (2006) Education sector development framework and programme (ESDFP) 2006. Battaramulla: Author.

Ministry of Human Resource Development, Government of India [MoHRDI] (2016) Some Inputs for Draft National Education Policy 2016. New Delhi: Author.

Ministry of Youth Affairs, Sri Lanka [MoYASL] (2007) Strategic assessment and policy recommendations for a National Action Plan for Youth Emploment Sri Lanka 2007. Battaramulla: Author.

Nalla S and Sanapala UK (2015) Importance of management education and its impact on entrepreneurship development in India. International Journal of Academic Research 2(7): $1-5$.

National Knowledge Commission [NKC] (2008) Entrepreneurship in India. Retrieved from https://india.gov.in/reports-national-knowledgecommission.

Nayar R and others (2012) South Asia development matters: More and better jobs in South Asia. Washington, D.C.: World Bank.

Oosterbeek H, Praag MV and Ijsselstein A (2010) The impact of entrepreneurship education on entrepreneurship skills and motivation. European Economic Review 54: 442 - 454. 
Parker, SC and Praag CM (2006) Schooling, capital constraints and entrepreneurial Performance: the endogenous triangle. Journal of Business and Economic Statistics 24: 416 431.

Priyanath HMS and Premaratne SP (2014) Government SME development programs in Sri Lanka: A review in the lens of transaction cost economics. Sabaragamuwa University Journal 13(2): 59 - 81.

Quiroz C (2002) Local knowledge systems and vocational education in developing countries. In: Semali LM, and Kincheloe JL (Eds) What is indigenous knowledge? pp. 305 - 316. New York: Falmer.

Rehman A (2006) Sustainability and the Economy: Higher Education in Science and Technology - A Silent Revolution, www.britishcouncil.org.

Reynar R (2002) Indigenous people's knowledge and education: A tool for development? In Semali LM, and Kincheloe JL (Eds), What is indigenous knowledge? pp. 285 - 304. New York: Falmer.
Royal Government of Bhutan [RGoB] (2013) Eleventh Five Year Plan (2013 - 2018). Thumpu: Gross National Happiness Commission.

Taiwo R and Tunde AJ (2016) Impact of education on national development. International Journal of Advanced Academic Research 2: 1 - 8 .

United Nations Economic and Social Commission for Asia and the Pacific [UN-ESCAP] (2011) Enabling environment for the successful integration of small and medium-sized enterprises in global value chains: Country studies on Bangladesh, Nepal and Sri Lanka. Bangkok: Author.

United Nations Economic and Social Commission for Asia and the Pacific [UN-ESCAP] (2011) Economic and social survey of Asia and the pacific 2015: Making growth more inclusive for sustainable development. Bangkok: United Nations Publication.

UNESCO (2007) World data on education (6th edition). Geneva: Author.

Vollmann W (2010) The challenges of technical vocational training and education in rural areas: The case of south Asia. Journal Education and Research 2: 52 - 58. 